University of Nebraska - Lincoln

DigitalCommons@University of Nebraska - Lincoln

Faculty Publications from the Harold W. Manter Laboratory of Parasitology

2005

\title{
LAELAPINE MITES (ACARI: LAELAPIDAE) ASSOCIATED WITH SMALL MAMMALS FROM AMAZONAS, BRAZIL, INCLUDING A NEW SPECIES FROM MARSUPIALS
}

\author{
Donald Gettinger \\ University of Nebraska-Lincoln, donaldgettinger@gmail.com \\ Fernanda Martins-Hetano \\ UERJ \\ Marcela Lareschi \\ Centro de Estudios Parasitológicos y de Vectore \\ Jay R. Malcolm \\ University of Toronto
}

Follow this and additional works at: https://digitalcommons.unl.edu/parasitologyfacpubs

Part of the Parasitology Commons

Gettinger, Donald; Martins-Hetano, Fernanda; Lareschi, Marcela; and Malcolm, Jay R., "LAELAPINE MITES (ACARI: LAELAPIDAE) ASSOCIATED WITH SMALL MAMMALS FROM AMAZONAS, BRAZIL, INCLUDING A NEW SPECIES FROM MARSUPIALS" (2005). Faculty Publications from the Harold W. Manter Laboratory of Parasitology. 685.

https://digitalcommons.unl.edu/parasitologyfacpubs/685

This Article is brought to you for free and open access by the Parasitology, Harold W. Manter Laboratory of at DigitalCommons@University of Nebraska - Lincoln. It has been accepted for inclusion in Faculty Publications from the Harold W. Manter Laboratory of Parasitology by an authorized administrator of DigitalCommons@University of Nebraska - Lincoln. 


\title{
LAELAPINE MITES (ACARI: LAELAPIDAE) ASSOCIATED WITH SMALL MAMMALS FROM AMAZONAS, BRAZIL, INCLUDING A NEW SPECIES FROM MARSUPIALS
}

\author{
Donald Gettinger, Fernanda Martins-Hatano*, Marcela Lareschi†, and Jay R. Malcolm $\neq$ \\ Harold W. Manter Laboratory of Parasitology, University of Nebraska, Lincoln, Nebraska 68858-0514. e-mail: donaldg@alltel.net
}

\begin{abstract}
An intensive survey of ectoparasitic arthropods associated with small mammals in upland forests near Manaus, Brazil, provides information on the taxonomy and host distribution of laelapine mites in the Amazonian Region. We identified 5 genera and 21 species of these mites by comparison with representative museum specimens, the taxonomic literature, and, when possible, the original type specimens. These mites are host specific, with associations ranging from strict monoxeny (18 species) to oligoxeny ( 1 species) and pleioxeny ( 2 species). Marsupials were infested with species of Androlaelaps, echimyid rodents with Tur, and sigmodontine rodents with Gigantolaelaps, Laelaps, and Mysolaelaps. Androlaelaps bergalloi, a new species of Laelapinae, is described from the pelage of the marsupial Monodelphis brevicaudata.
\end{abstract}

Mesostigmatic mites of the Laelapinae Berlese, 1892 (Acari: Laelapidae) are common associates of small mammals worldwide but reach an extremely high diversity in the neotropics. They are often abundant in host pelage and usually the predominant group of arthropods sampled from neotropical rodents and marsupials. Unfortunately, very little information is available on the host and geographic distribution of these mites in the Amazonian Region. Of the 8 genera and ca. 67 species of laelapines presently recognized on neotropical small mammals, only 5 genera and 13 species are known from the Brazilian Amazon (Rebello et al., 2004). In this study, we present a species inventory of laelapine mites collected in an intensive study of small mammals in upland Amazonian forests near Manaus, Brazil, and formally describe a new species associated with the marsupial Monodelphis brevicaudata (Erxleben, 1777). The prevalence and intensity of mite infestations are used to evaluate host specificity and to establish patterns of association across the small-mammal community.

\section{MATERIALS AND METHODS}

Between 1983 and 1988, small mammals and their associated arthropods were collected from isolated and nonisolated primary forest reserves approximately $80 \mathrm{~km}$ north of Manaus $\left(2^{\circ} 25^{\prime} \mathrm{S}, 59^{\circ} 53^{\prime} \mathrm{W}\right)$ Amazonas, Brazil, by J.R.M.. These studies were carried out as a part of the Minimum Critical Size of Ecosystems project, a collaboration between World Wildlife Fund (WWF) and the Instituto Nacional de Pesquisas da Amazônia (INPA), and later named the Biological Dynamics of Forest Fragments Project, a collaboration between the Smithsonian Institution and INPA. A diverse community of small mammals was sampled for ectoparasites, including the marsupials Caluromys philander (Linnaeus, 1758), Micoureus demerarae (Thomas, 1905), Marmosa murina (Linnaeus, 1758), Metachirus nudicaudatus (Desmarest, 1817), and $M$. brevicaudata (Erxleben, 1777); the sigmodontine rodents Rhipidomys mastacalis (Lund, 1840), Oryzomys macconnelli Thomas, 1910, Neacomys guianae Thomas, 1905, Oecomys paricola (Thomas, 1904), Oecomys bicolor (Tomes, 1860); and the hystricognath rodents Mesomys hispidus (Desmarest, 1817) and Proechimys cayennensis (Desmarest, 1817) (=guyannensis). For more information on the study areas and the small-mammal fauna, see Malcolm (1991a, 1991b).

Ectoparasites were brushed from the mammals in the field and stored in $70 \%$ ethanol. In the laboratory, representative specimens were mount-

Received 24 February 2004; revised 21 June 2004; accepted 21 June 2004.

* Departamento de Ecologia, IBRAG, UERJ, Rua Cardoso Júnior, 454, ap. 201, Laranjeiras, RJ, Brazil 20550-011.

$\dagger$ Centro de Estudios Parasitológicos y de Vectores, Calle 2 No. 584, 1900 La Plata, Argentina.

$\ddagger$ Faculty of Forestry, University of Toronto, Toronto, Ontario, Canada M5S 3B3. ed individually in Hoyer's medium, ringed with Glyptal, and measured with a stage-calibrated ocular micrometer. All measurements are in micrometers $(\mu \mathrm{m})$; when referring to more than 1 specimen, measurements are given as the mean, followed by the range in parentheses. We follow Wilson and Reeder (1993) for mammalian taxonomy and nomenclature. All mammal voucher specimens are deposited in the United States National Museum (USNM) and in Brazil at the INPA, Manaus, Amazonas, Brazil. Arthropods are in the Collection of Entomology at INPA. Basic parasite population indices were used to estimate association between a particular mite species and its host, i.e., the prevalence of infestation (proportion of individuals of a given host species that were infested) and the intensity of infestation (mean number of mites per host sampled). The following formal species description was provided by DG.

\section{DESCRIPTION}

\section{Androlaelaps bergalloi, n. sp.}

(Figs. 1-3)

Dorsum (Fig. 1): Dorsal shield entire, oblong, fused to peritremalia lateral to $\mathrm{j} 1-\mathrm{z} 1$, lateral margins parallel over coxae IIIV, surface reticulate, with 39 consistent pairs of strong, lightly barbed setae; $j / J$ series complete and $z / Z, s / S, r / R$ series nearly or also complete; j5 reaching well posterior to base of $\mathrm{z} 5$; J5 long, more than half the length of Z5; 1-3 unpaired seta medially between $\mathrm{J} 1$ and $\mathrm{J} 4$; glands and pores as illustrated. Unarmed dorsum with submarginal series of long setae.

Venter (Fig. 3): Sternal shield wider than long, broadest at posterolateral angles; anterior margin nearly straight, bearing the first pair of sternal setae; lateral and posterior shield margins slightly concave; surface sculpturing strongly reticulate marginally, lightly reticulate-punctate medially; presternal region strongly reticulate, extending to base of tritosternum; st 1 long, extending well beyond base of st2, which extends beyond base of st3; first 2 pairs of pores on shield, elongate and lyriform, first pair oriented horizontally, second pair strongly angled anteromedially. Metasternal setae on medial margin of endopodal shields; third pair of small lyriform pores on unarmed integument, oriented almost vertically. Epigynial shield linguiform, slightly expanded posterior to genital setae, rounded posteriorly; surface of shield reticulate. Metapodal shields small, oblong, and oriented longitudinally. Opisthogastric setae long and lightly barbed. Peritremes long, extending anteriorly to a point over coxa I (just anterior to s1 of dorsal shield); peritrematic shield extending posterior to stigma for a distance ca. twice the diameter of the stigma, medially into the interspaces between coxa I, II, and III, and turning dorsad anterior to peritreme to fuse with dorsal shield lateral to $\mathrm{j} 1 / \mathrm{z} 1$. Anal shield broadly pyriform, length subequal to width, with anterior margin slightly 


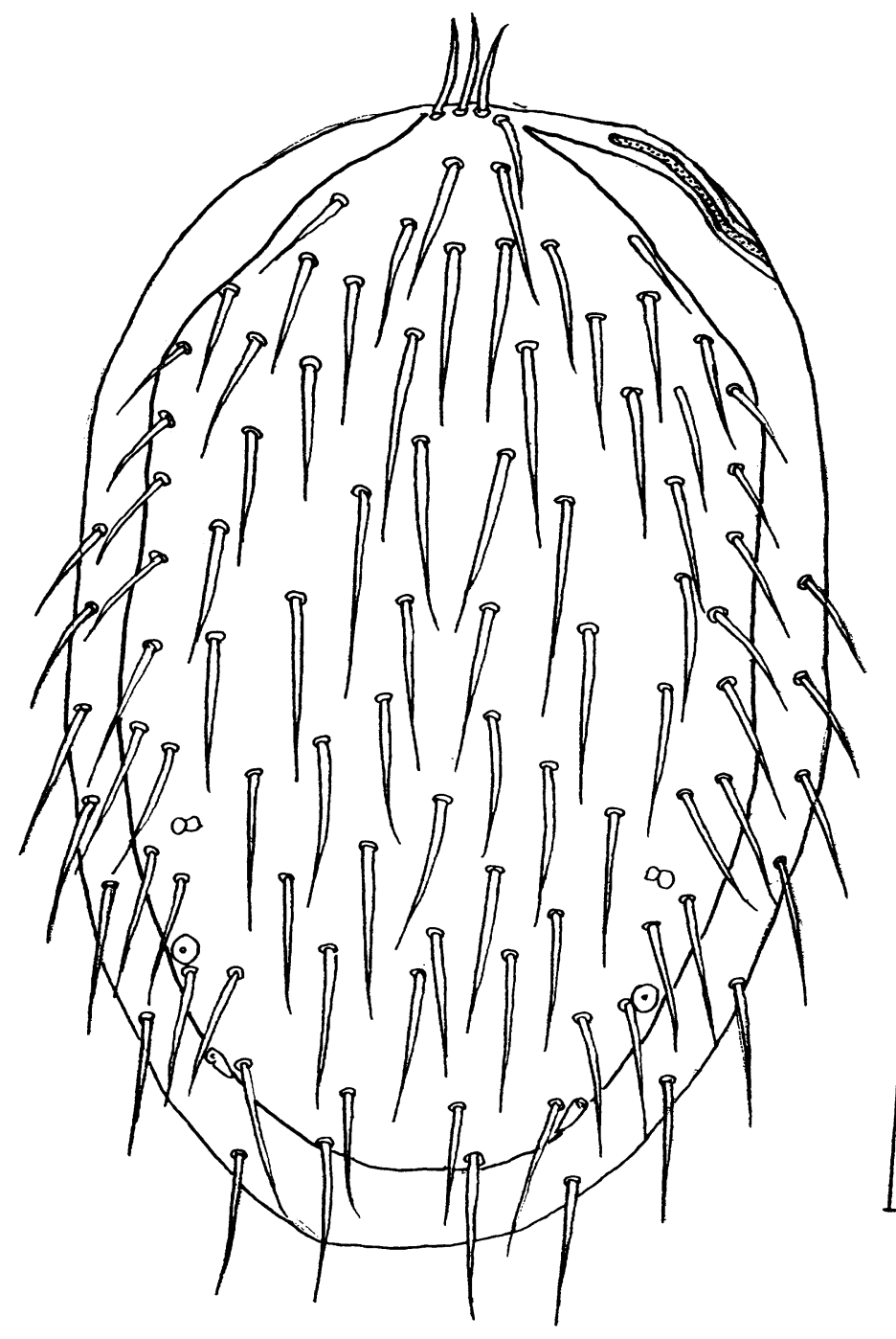

1

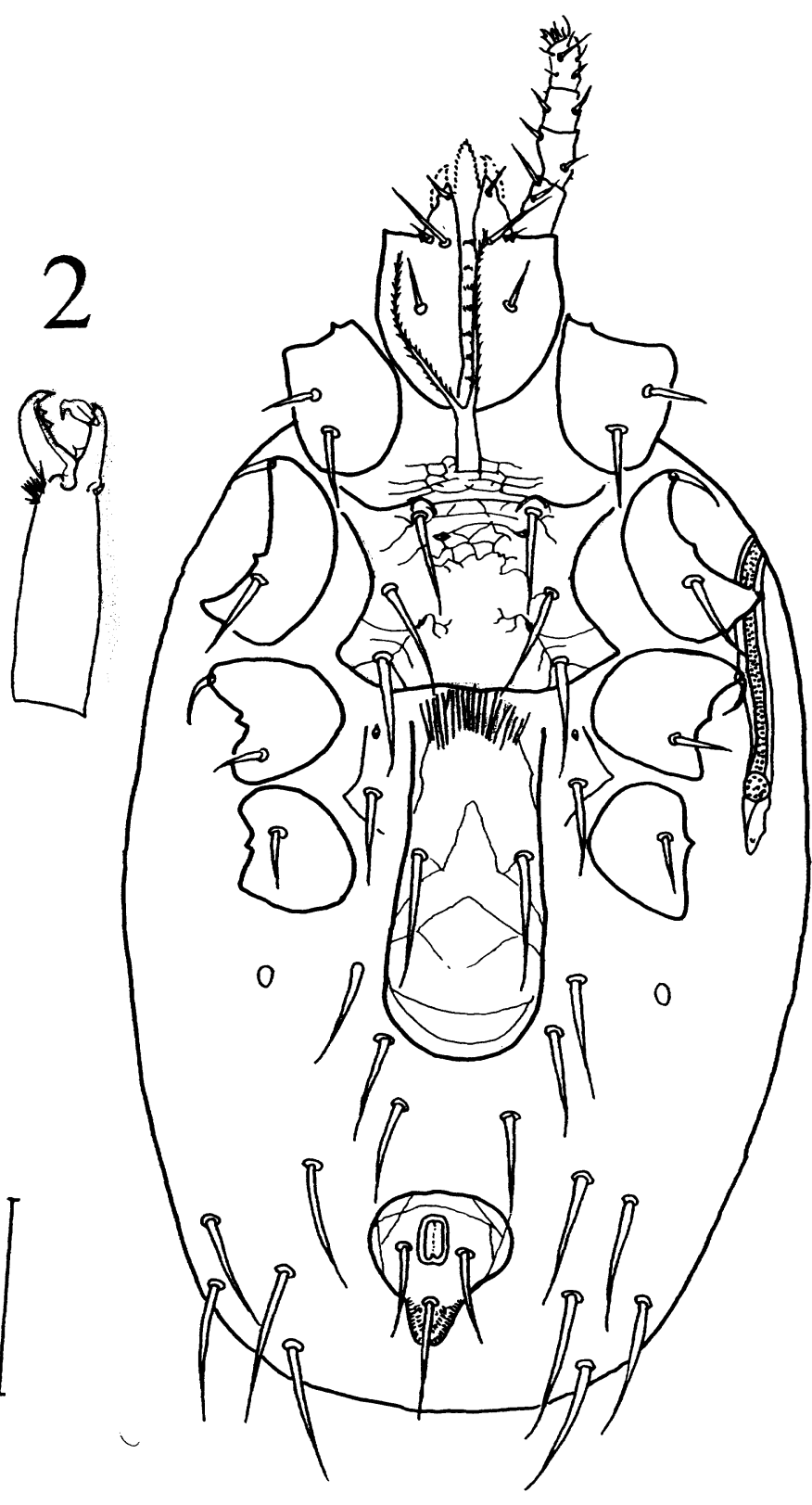

3

Figures 1-3. Androlaelaps jaymalcolmi, n. sp., female. 1. Dorsum. 2. Chelicera. 3. Venter. Bar $=150 \mu \mathrm{m}$.

arched; paranal setae long, extending posterior to shield; postanal seta about $25 \%$ longer than paranals; cribrum with about 3 rows of teeth, extending laterally to a point anterior to level of postanal setal insertion.

Gnathosoma: Epistome simple, anteriorly lobate. Chelicerae (Fig. 2) thick and chelate-dentate; arthrodial processes well developed; movable digit with 2 strong teeth, a hooked tip; fixed digit with 2 small teeth; pilus dentilis broadly inflated basally, with an inflated recurved tip. Tritosternum typically laelapine; gnathosomatic chaetotaxy normal; order of setal length from longest: inner hypostomals, gnathosomals, anterior hyposto- mals, outer hypostomals; deutosternal groove with 6-7 rows of anteriorly directed teeth; corniculi (external malae) strongly sclerotized and bladelike; internal malae broad, fringed laterally; labrum striated lengthwise, spinose, pointed, extending anterior to corniculi. Palpal chaetotaxy holotrichous (2-5-6-14$15), v 2$ of trochanter very long (longer than anterior hypostomal setae), tarsal apotele long and 2-tined.

Legs: All of moderate length and thickness; legs I and IV subequal in length, longer than legs II and III. Chaetotaxy (from coxa to tarsus omitting tarsus I) holotrichous for a dermanyssoid: $\mathrm{I}=2,6,13,13,13$, - $; \mathrm{II}=2,5,11,11,10,18$; III = 
TABLE I. Host-mite associations in upland forests $80 \mathrm{~km}$ north of Manaus, Amazonas, Brazil.

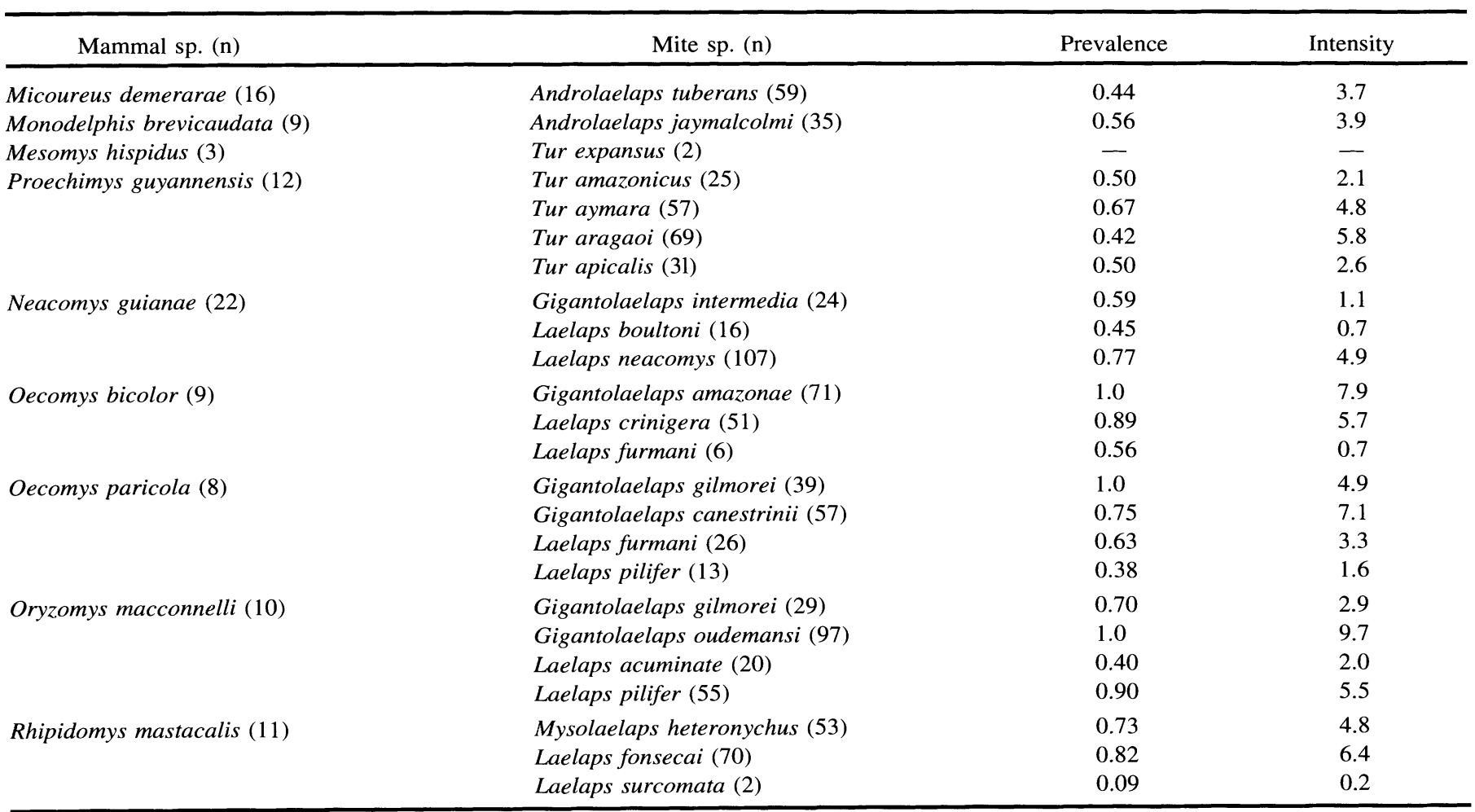

$2,5,6,9,8,18 ; \mathrm{IV}=1,5,6,10,10,18$. All leg setae are smooth, simple setiforms; ad1 and pd1, subtending the ambulacrum on each of tarsi II-IV, are very small.

Measurements: (Sixteen specimens)-dorsal shield length, 840 (822-860); dorsal shield width, 513 (495-524); j1, 70 (6673); j5, 147 (144-150); z5, 148 (141-155); J5, 96 (93-99); Z5, 136 (129-140); gnathosomal seta, 45 (43-47); inner hypostomal seta, 70 (68-73); sternal shield length, 133 (128-137); sternal shield width, 164 (156-170); sternal seta 1, 85 (80-89); sternal seta 3, 97 (90-103); sternal seta 4, 81 (78-84); epigynial seta, 113 (109-118); paranal seta, 77 (73-80), postanal seta, 100 (96-106), greatest width anal shield, 134 (128-140), proximal seta coxa I, 60 (58-63), posterior seta coxa II, 77 (7480).

Diagnosis: Females of $A$. bergalloi are large (dorsal shield length greater than $800 \mu$ ), with 39 pairs of long, lightly barbed setae and 1-3 unpaired accessory setae along midline of posterior shield; known only from pelage of M. brevicaudata. Androlaelaps bergalloi Gettinger is morphologically similar to $A$. hirsuta Furman, 1972; both have the fixed digit of the chelicerae with pilus dentilis inflated distal to the point of insertion, i.e., subgenus Ischnolaelaps sensu Fonseca, 1958. Androlaelaps bergalloi can easily be distinguished from $A$. hirsuta by larger body size and a lack of extreme hypertrichy of the dorsal shield and unarmed opisthosoma.

\section{Taxonomic summary}

Type hosts: Monodelphis brevicaudata (Erxleben, 1777), (Mammalia: Didelpimorphia: Didelphidae), specimen INPA20893 (NC-3527), collected 4 April 1988, located in the mammal collection at INPA, Manaus, Brazil, is designated as ho- losymbiotype. Monodelphis brevicaudata, specimen USNM579979 (NC-3480), collected 31 March 1988, located in the mammal collection at the National Museum of Natural History, Smithsonian Institution, designated as parasymbiotype.

Type locality: Brazil, Amazonas, ca. $80 \mathrm{~km}$ north of Manaus, PDBFF, Fazenda Esteio ( $\left.2^{\circ} 24^{\prime} \mathrm{S}, 59^{\circ} 53^{\prime} \mathrm{W}\right)$, near the camp ' $\mathrm{Ci}$ dade Powell."

Specimens deposited: Holotype and 3 paratypes at the INPA, Manaus, Brazil; 4 paratypes at the Instituto Butantan, São Paulo, Brazil; 2 paratypes at the Museu de Zoologia, Universidade de São Paulo, São Paulo, Brazil; 3 paratypes at the Harold W. Manter Laboratory of Parasitology, University of Nebraska, Nebraska, Lincoln; 3 paratypes at the Field Museum of Natural History, Chicago, Illinois.

Etymology: The specific epithet of $A$. bergalloi is a patronym honoring Dr. Helena Godoy Bergallo and her work with both brazilian mammals and their ectoparasites and also for her helpful guidance and support on this project.

Biology: The type series of 16 females comprised 3 reproductive females, each carrying a single larva, 12 females with single eggs, and 1 female of undetermined status. No males or immature stages was collected.

\section{RESULTS}

Twenty-one nominal species of laelapine mites (1,014 specimens), representing 5 genera were collected from small mammals in this survey (Table I). The genus Androlaelaps Berlese (2 spp.) was collected from marsupials; the genus Gigantolaelaps Fonseca (5 spp.), Mysolaelaps Fonseca (1 sp.), and Laelaps Koch (8 spp.) from sigmodontine rodents; and the genus Tur Baker \& Wharton (5 spp.) from hystrichognath rodents. The 
associations with their small-mammal hosts were highly specific at the species level; 18 of 21 mite species were reported infesting a single host species (monoxenous), 1 species infesting only congeneric hosts (oligoxenous), and 2 infesting hosts of the same rodent tribe (pleioxenous). Laelapine mites were collected from all rodent species but only 2 of 5 marsupial species sampled; no mites was collected from $C$. philander, $M$. murina, or $M$. nudicaudatus in this survey.

The following mite-host associations were identified (see Table I): Androlaelaps tuberans Furman, 1972 ex. M. demerarae; A. bergalloi Gettinger ex. M. brevicaudata; Mysolaelaps heteronychus Fonseca, 1959 and Laelaps fonsecai Gettinger, 1992 ex. R. mastacalis; Gigantolaelaps intermedia Furman, 1971, Laelaps boultoni Furman \& Tipton, 1961 and Laelaps pilifer Tipton 1966, ex. N. guianae; Gigantolaelaps canestrinii Fonseca, 1959, Laelaps crinigera Furman, 1972, and Laelaps furmani Gettinger, 1992 ex. O. bicolor; Gigantolaelaps gilmorei Fonseca, 1939, Gigantolaelaps oudemansi Fonseca, 1939, L. furmani, and L. pilifer ex. O. paricola; G. gilmorei, G. oudemansi, L. pilifer, and L. acuminata Furman, 1972 ex O. macconnelli; Tur expansus Furman, 1972 ex. M. hispidus; T. amazonicus Fonseca, 1960, Tur apicalis Furman and Tipton, 1961, Tur aragaoi (Fonseca, 1939) and Tur aymara Fonseca, 1960 ex. Proechimys guyannensis.

\section{DISCUSSION}

It is clear that more survey work will be necessary to achieve any realistic estimates of the diversity and species abundance of laelapine mites associated with small mammals in the Amazonian Region. The results of this small survey, from a single locality, have nearly doubled the number of species recently known from the Brazilian Amazon (to 5 genera and 25 species), as reported by Rebello et al. (2004). Also, 19 of the 21 mite species were recorded on 7 species of oryzomyine and echi- myid hosts, and these rodent groups are important components of the Amazonian small-mammal fauna. We can expect to find a comparable laelapid mite community infesting the unsampled rodents in the Amazon.

Of the 21 species of laelapine mites identified in this survey, 16 are recorded here for the first time in the Brazilian Amazon (A. bergalloi, A. tuberans, G. amazonae, G. intermedia, L. acuminata, $L$. boultoni, $L$. crinigera, $L$. fonsecai, $L$. furmani, $L$. neacomyos, $L$. pilifer, $L$. surcomata, $T$. apicalis, $T$. aragaoi, $T$. aymara, and $T$. expansus) and 2 are relatively new to science (L. neacomydis Gettinger \& Gardner, 2003 and A. bergalloi Gettinger, this article).

\section{ACKNOWLEDGMENTS}

This work was carried out while the senior author was visiting the Universidade do Estado do Rio de Janeiro as a Fulbright Scholar. Thanks to the friendly and interactive faculty and students in the Department of Ecology and the special attention of Helena Godoy Bergallo and Carlos Frederico Duarte Rocha, we were able to work productively. Thanks also to Darci Moraes Barros Battesti and Daniel Bacelar da Costa of the Laboratório de Parasitologia, Instituto Butantan, for providing access to and help with the Flavio Fonseca type collection. Work on small mammals greatly benefited from the assistance of Rob Bierregaard and was supported by World Wildlife Fund-U.S., the National Geographic Society, the Tinker Foundation, and Sigma Xi.

\section{LITERATURE CITED}

MALCOLM, J. R. 1991a. The small mammals of tropical forest fragments: Patterns and process. PhD. Dissertation. University of Florida, Gainesville, Florida.

. 1991b. Comparative abundances of Neotropical small mammals by trap height. Journal of Mammalogy 72: 188-192.

Rebello, V. M. M., D. B. Costa, D. Gettinger, A. D. Brescovit, AND D. M. BARROS-BATteSTI. 2004. Acari-gamasida-Laelapidae-Parasitic mites. Revista Fauna da Amazonia Brasileira. [In press.]

WILSON, D. E., AND D. M. REEDER. 1993. Mammal species of the world: A taxonomic and geographic reference. Smithsonian Institution Press, Washington, D.C., 1207 p. 